\title{
Intrascleral ocular prosthesis following evisceration in thirteen horses
}

\author{
József Tóth, Stefanie Huthmann and Lieke Dikker \\ Tierärztliche Klinik Domäne Karthaus, Dülmen
}

\begin{abstract}
Summary : A multitude of ocular diseases can lead to a loss of vision and permanent ocular pain in horses. The present paper addresses the topic of cosmetic and reconstructive surgery in equine ophthalmological patients based on the implantation of intrascleral silicone prostheses. Thirteen horses aged between four and twenty years with various ocular problems requiring removal of a blind and/or painful eye were placed under general anaesthesia. After evisceration of the globe, a silicone prosthesis was introduced into the sclera. Sclera and conjunctiva were sutured and the horses were treated with NSAIDs and ophthalmic ointments postoperatively. After healing of the surgical wound, a dark tinted bandage lens could be placed over the eye by the owner to further enhance the cosmetic result. The surgical wounds healed well in all horses. One horse had a deep corneal ulceration and the prosthesis had to be removed two weeks after surgery. Two horses developed eosinophilic keratitis six and eight weeks after surgery, respectively. The condition was repeatedly treated with a diode laser and ophthalmic ointments and resolved subsequently. One horse showed transient swelling in the surroundings of the eye that resolved within two days. The corneas of the eyes that underwent surgery passed through various stages of cloudiness and vascularization, as well as epithelial reconstruction, followed by pigmentation. Intrascleral silicone prostheses in combination with a dark tinted bandage lens yield a cosmetically excellent result that is well received by the owners. It serves as a cosmetically superior alternative to plain enucleation or enucleation and subsequent placement of an intraorbital prosthesis in cases where the removal of a blind and/or painful eye is inevitable.
\end{abstract}

Keywords: eye / horse / silicone / prosthesis / evisceration / pain / ophthalmology

Citation: Tóth J., Huthmann S., Dikker L. (2014) Intrascleral ocular prosthesis following evisceration in thirteen horses. Pferdeheilkunde $30,153-160$

Correspondence: Prof. Dr. Dr. József Tóth, Tierärztliche Klinik Domäne Karthaus, Weddern 16c, 48249 Dülmen, Germany, E-Mail: prof.toth@tierklinik-karthaus.de

\section{Introduction}

A multitude of ocular diseases can lead to a loss of vision and permanent ocular pain in horses. By far the most common reason for this is equine recurrent uveitis. Traumatic injuries, glaucoma, and ocular neoplasia must be stated as further more common causes. The goals of any veterinary ocular therapy, normal vision and analgesia, cannot always be achieved in these cases. If the diseased and often painful globe cannot be salvaged it needs to be removed. However, many horse owners are offended by the sunken appearance of an enucleated eye. To them, it is important to preserve the natural beauty and unscathed exterior of their horses. In addition to this aesthetic and emotional problem, the loss of an eye can be an economic problem due to the loss in value of the animal (Gilger et al. 2003, Hamor et al. 1992, Michau and Gilger 2004, Riggs and Whitley 1990, Ruehli et al. 1999, Severin 1998, Toth and Hollerrieder 1999, Toth at al. 2011). In such cases, it is the responsibility of the veterinary surgeon to find a solution that provides both a permanent analgesia to the horse as well as a cosmetically acceptable result for the owner (Riggs and Whitley 1990, Toth at al. 2011).

Ocular cosmetic surgery and ocular prostheses have a long history in veterinary medicine. The materials employed not only depend on the respective period they were used, but also on the intended surgical procedure, e. g. intraorbital placement, scleral shell prosthesis or intrascleral placement. Materials such as horn, glass, rubber, silicone, methylmethacrylate, plastic, silver wire mesh, porcelain, and hydroxyapatite are described in literature (Dortzbach and Woog 1985, Gelatt and Whitley 2011, Gilger et al. 2003, Hamor et al. 1993, McMullen et al. 2010, Meek 1988, Pierce and Townsend 2012, Provost et al. 1989, Riggs and Whitley 1990, Ruehli et al. 1999, Severin 1998, Shields et al. 1993, Toth and Hollerrieder 1999, Toth et al. 2011, Wilkie et al. 1994). In human patients, the most commonly used material for intrascleral prostheses is hydroxyapatite, a marine coral (Gilger et al. 2003, Shields et al. 1993). Recently, this material has also been successfully employed as intrascleral prosthesis in a horse (Gilger et al. 2003). Silicone is widely used in veterinary medicine as implant material in both intraocular as well as intrascleral prostheses as it is relatively low-priced, pliable and can be sterilized (Gelatt and Whitley 2011, Gilger et al. 2003, Hamor et al. 1993, Meek 1988, Provost et al. 1989, Riggs and Whitley 1990, Severin 1998, Toth and Hollerrieder 1999, Toth et al. 2011, Wilkie et al. 1994).

While the placement of intraorbital prostheses is a common procedure in equine medicine that can also be accomplished in the standing horse, the implantation of intrascleral prostheses is not so frequently performed in horses. In other species, e. g. dogs with chronic glaucoma, the implantation of intrascleral prostheses is more commonly attained and severe complications are rare (Hamor et al. 1993, Nasisse et al. 1988, Riggs and Whitley 1990, Toth and Hollerrieder 1999).

The selection criteria for the placement of intrascleral prostheses are restricted in equine patients. Infected eyes and eyes affected by neoplasia must be carefully evaluated for their suitability (Dortzbach and Woog 1985, Pierce and Townsend 2012, Provost et al. 1989, Riggs and Whitley 1990, Ruehli et 
al. 1999, Shields et al. 1993, Toth et al. 2011 ). Eyes with corneal or scleral lacerations bear a poorer prognosis for surgical correction than intact eyes (Pierce and Townsend 2012, Riggs and Whitley 1990). Horses suffering from chronic glaucoma, those with phthisis bulbi, and those with blind, painful eyes or traumatic injuries are candidates for the placement of intrascleral prostheses (Gelatt and Whitley 2011, Gilger and Mclaughlin 1993, Provost et al. 1989, Riggs and Whitley 1990, Toth et al. 2011). In summary, the requirements for this surgery are ideally an intact sclera, a healthy cornea, and a functioning tear film as well as normal function of the eyelids (Gilger and McLaughlin 1993, Toth et al. 2011 ).

\section{Material and Methods}

\section{Cases}

In the time between December 2011 and October 2013, thirteen equine patients of the Tierklinik Domaene Karthaus, suffering from various ocular problems (see below), were chosen suitable for the placement of an intrascleral silicone prosthesis (Table 1).

Horse 1 was a 12 year-old riding pony gelding that had a history of left-sided recurrent uveitis reaching back more than four years. At the initial examination it was determined that the prognosis for the left eye was poor as there was a large amount of floating membranes and a retinal detachment on ultrasonographic examination. The eye was blind and permanently painful and a surgical enucleation of the globe was recommended. Since the owner wanted to continue using the pony as a show horse he asked for a surgical treatment that offered both permanent analgesia and an acceptable cosmetic result.

Horse 2 was a four year-old Holstein gelding that was presented to the hospital's emergency service with a perforating corneal laceration of the right eye. According to the owner, the horse had hurt his eye on the chain he had been tied with.
The laceration was approximately $1 \mathrm{~cm}$ in length; iris and vitreous body were prolapsed. Hyphaema and a marked miosis were present in the eye. The horse was placed under general anesthesia, the laceration was sutured and anterior as well as posterior chamber were subjected to a vitrectomy. About a month after surgery, the corneal laceration had healed well but a phthisis bulbi had occurred due to a profound post-surgical uveitis. As the horse was still young and talented, the owner wanted to use it as a sport horse and thus asked for a cosmetically acceptable solution.

Horse 3 was a 14 year-old Quarter Horse mare with a longlasting history (several years) of ocular problems due to equine recurrent uveitis. The mare had had a vitrectomy of the right eye five years prior to referral. At the time of referral, the right eye showed a cloudiness of the cornea, corneal ulceration, corneal neovascularization and an anterior lens luxation. The eye was extremely painful and removal of the painful globe was recommended. As the horse was an experienced and valuable show horse the owner wanted as good a cosmetic result as possible.

Horse 4 was a 20 year-old Shetland pony mare with a history of recurrent uveitis of the left eye. Despite vitrectomy two years prior, the left eye kept relapsing with episodes of uveitis. At the time of examination, the left eye had an acute inflammatory episode with a corneal ulceration of approximately $1 \mathrm{~cm}$ size that penetrated into the stroma. The owner wanted an end to the permanent inflammation but also a good cosmetic appearance as the mare was a show horse.

Horse 5 was a 14 year-old Westphalian gelding that had been treated for approximately two months due to ocular problems prior to referral. Upon referral, the gelding displayed blepharospasm, epiphora, photophobia, miosis and corneal cloudiness of the right eye. A fluorescein stain test was negative but ultrasonographic examination revealed floating membranes in the vitreous body. The gelding was diagnosed with equine recurrent uveitis of the right eye. Despite medical treatment the gelding kept having episodes of uveitis, regu-

Table 1 Overview of the thirteen cases treated with intrascleral ocular prostheses. / Überblick über die dreizehn Patienten, die nach Eviszeration des Bulbus mit intraskleralen Silikonimplantaten versorgt wurden.

\begin{tabular}{|c|c|c|c|c|c|c|c|}
\hline Case & $\begin{array}{c}\text { Age } \\
\text { (years) }\end{array}$ & Gender & Breed & Use & Diagnosis & Result & $\begin{array}{c}\text { Observation } \\
\text { period (months) }\end{array}$ \\
\hline 1 & 12 & Gelding & Riding pony & Show horse & ERU & Good & 35 \\
\hline 2 & 4 & Gelding & Warmblood & Sport horse & Trauma & Good & 21 \\
\hline 3 & 14 & Mare & Quarterhorse & Show horse & ERU & Good & 19 \\
\hline 4 & 20 & Mare & Shetland Pony & Show horse & ERU & Prosthesis failure & 17 \\
\hline 5 & 14 & Gelding & Warmblood & Sport horse & ERU & Good & 16 \\
\hline 6 & 12 & Gelding & Warmblood & Sport horse & ERU & Good & 15 \\
\hline 7 & 7 & Gelding & Warmblood & Sport horse & ERU & Good & 7 \\
\hline 8 & 15 & Mare & Icelandic Horse & Therapy horse & ERU & Good & 6 \\
\hline 9 & 9 & Gelding & Knabstrupper & Show horse & ERU & Good & 6 \\
\hline 10 & 12 & Mare & Warmblood & Sport horse & Keratitis vasculosa & Good & 3 \\
\hline 11 & 7 & Gelding & Warmblood & Sport horse & Keratitis vasculosa & Good & 3 \\
\hline 12 & 9 & Mare & Warmblood & Sport horse & Corneal laceration, uveitis & Good & 1 \\
\hline 13 & 13 & Gelding & Warmblood & Sport horse & Keratitis & Good & 1 \\
\hline
\end{tabular}

$y=$ years; ERU = equine recurrent uveitis 
larly with corneal ulceration. The gelding received an intravitreal injection with gentamicine but the eye kept showing signs of inflammation. A corneal ulcer developed that was refractory to any medical treatment. When the removal of the eye was proposed, the owners wished for an acceptable cosmetic appearance as the horse was used as a sport horse. The owners were informed that the existing corneal ulceration posed a particular risk to the succesful outcome of the planned surgery.

Horse 6 was a 12 year-old Westphalian gelding that had been previously diagnosed with equine recurrent uveitis of the right eye. The gelding had received a suprachoroidal cyclosporine implant two years prior to referral but still had recurrent episodes of uveitis. Recently, the owner had noticed a red cloudiness in the eye. Upon presentation, the gelding displayed blepharospasm, corneal cloudiness, hyphaema, lens cataract, and phthisis bulbi. Ultrasonographic examination disclosed large amounts of floating membranes in the vitreous body as well as retinal detachment. The eye was extremely painful and an enucleation was recommended. As the horse was a highly successful dressage horse competing at international levels, the owners opted for a surgical treatment with an enhanced cosmetic result.

Horse 7 was a seven year-old Trakehner gelding that had been purchased as a competition horse. An ophthalmologic problem had been diagnosed in the left eye during the prepurchase examination one and a half years prior to the first presentation and the horse kept having trouble with that eye. Upon presentation, the gelding had blepharospasm of the left eye, showed no reaction to light or menace and the cornea was cloudy. At the nasal canthus a hyphaema could be detected and in the central cornea two fluorescein-positive corneal defects were present. The lens was luxated to the anterior chamber and there was blood present in the vitreous body. Since the horse was a competition horse for the owner's daughter, the owners decided against the removal of the globe and wanted a cosmetically acceptable solution.

Horse 8 was a 15 year-old Icelandic mare that had received a vitrectomy due to equine recurrent uveitis of the left eye 12 years ago. The horse kept having acute episodes of uveitis and eventually developed glaucoma. Upon presentation the horse displayed a slight corneal cloudiness, synechias, a cataract and floating membranes in the vitreous body. As the horse was used in a therapy program for disabled children, the owners decided on surgery with a good cosmetic result.

Horse 9 was a nine year-old Knabstrupper gelding that had had a vitrectomy in the left eye due to equine recurrent uveitis a year ago. The horse had recently suffered a severe episode of uveitis that was followed by phthisis bulbi. On presentation, the gelding displayed blepharospasm, epiphora, reddened conjunctivae, hyphaema and miosis. As the horse is a show horse, the owner asked for a surgical solution with a good cosmetic result.

Horse 10 was a 12 year-old Dutch warmblood mare with a keratitis vasculosa in her right eye. The keratitis had been recognized and treated for a period exceeding two years. During this time, the mare had received a subscleral cyclosporine implant, but the episodes kept recurring. When the horse was presented to the clinic, the keratitis was refractive to therapy and, according to the owner, the horse had started to behave aggressively due to the constant pain. Upon presentation, the surroundings of the right eye were swollen. The horse had epiphora, blepharospasm and a fine vascularization of the cornea as well as a cloudiness were detected. The horse was a dressage horse participating in competitions and the owners required a surgical option with an acceptable cosmetic result.

Horse 11 was a seven year-old Dutch warmblood gelding with a keratitis vasculosa of the left eye. The condition had been treated unsuccessfully for six weeks, including cortisone therapy, and the eye was extremely painful. On presentation, there was blepharospasm and epiphora of the left eye. Also, a cloudiness of the cornea as well as superficial and deep vascularization of the cornea were present. This horse was also a promising dressage prospect and the owners asked for a surgical solution with an acceptable cosmetic appearance.

Horse 12 was a nine year-old Rhineland mare that had originally been referred to the clinic with a foreign body-induced corneal laceration of the right eye, subsequent fungal infection and secondary uveitis. The laceration was treated medically and with a conjunctival pedicle flap, the uveitis was treated medically. The flap healed well but the horse kept having episodes of uveitis that were refractory to medical treatment so that the mare underwent vitrectomy. Ten days after vitrectomy, another, albeit milder, episode of uveitis occurred. At that time, the right globe was already markedly smaller than the left. As the horse was a successful show jumper, the owner asked for an intrascleral implant to maintain a cosmetically acceptable appearance.

Horse 13 was a 13 year-old Dutch warmblood gelding that had been having recurrent episodes of keratitis in the left eye for years. According to the owner and the referring veterinarian, the episodes were occurring more frequently, were getting difficult to treat medically and also getting increasingly painful. Upon presentation, the cornea of the left eye was largely cloudy and there was a marked loss of vision. The horse showed epiphora and was very painful on examination. Due to the recurrent character of the condition, the loss of vision and the increasing painfulness, the removal of the painful eye was recommended. The horse had previously been used as a three-day eventing horse and the owner wished to use him as a dressage horse in competitions following surgery.

\section{Surgical procedures and post-surgical treatment}

Prior to surgery, all horses received a single "one-shot" antibiotic treatment (cefquinom $2.5 \mathrm{mg} / \mathrm{kg}$ intravenously) and the correct prosthesis size was determined depending on the data collected during the pre-surgical ultrasonographic examination. The surgery was performed under general anesthesia in lateral recumbency with the affected side on top. After surgical preparation of the affected eye, retention stitches (Safil ${ }^{\circledR}$ USP 0, B. Braun Melsungen AG, Germany; polyglycolic acid) were placed in the limbal sclera. The surgical approach through the sclera was carried out under the protection of a conjunctival flap. For this purpose, the conjunc- 
tiva was dissected approximately $10-12 \mathrm{~mm}$ posterior to the limbus. The sclera was then incised in an arcuated fashion from approximately $120^{\circ}$ to $180^{\circ}$ (Fig. 1). The incision was carefully continued centrally to the chorioidea. Special care was taken to protect the corneal endothelium. The uvea was truncated with scissors at its insertion at the optical nerve without damaging the sclera. The remaining uvea was bluntly dissected from the underlying layer to minimize hemorrhage as blood remaining in the globe increases the risk of infection. The globe was carefully enucleated with a bone

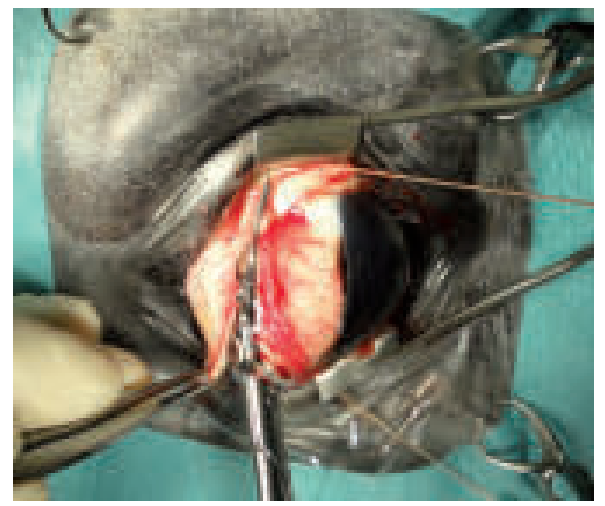

Fig. 1 Right eye of a 12 year-old Dutch warmblood mare during surgery (horse 10). Note the retention stitches in the limbal sclera to keep the globe in position during surgery. A conjunctival flap has been dissected and the sclera is incised in an arcuated fashion. Special care must be taken to protect the corneal endothelium from trauma.

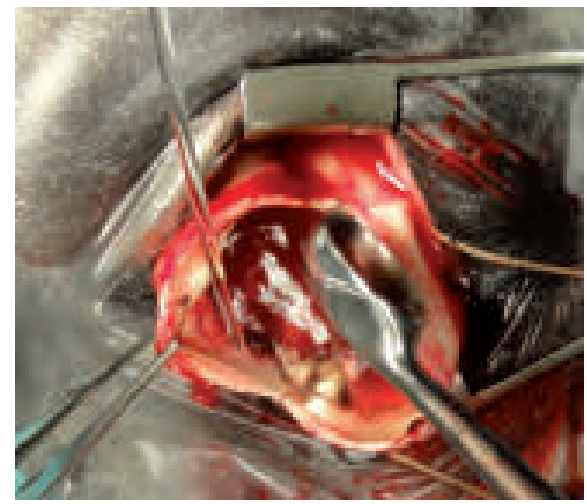

Fig. 2 Right eye of a 12 year-old Dutch warmblood mare during surgery (horse 10). The globe has been carefully enucleated with a bone curette and is now being flushed with balanced salt solution.

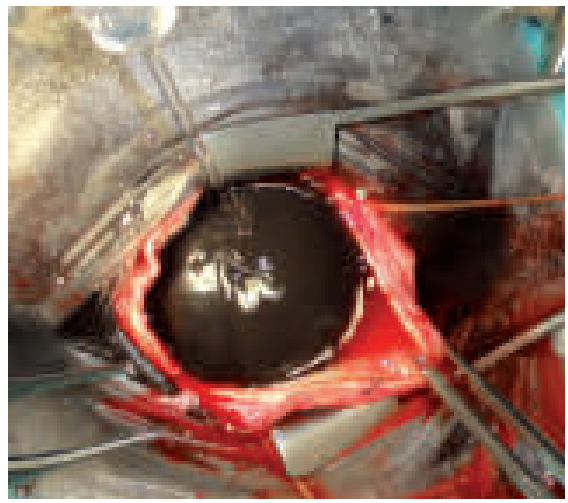

Fig. 3 Right eye of a 12 year-old Dutch warmblood mare during surgery (horse 10). The silicone prosthesis was carefully inserted into the eviscerated globe. Remaining blood is being flushed out with balanced salt solution. curette and the remaining cavity was flushed with balanced salt solution (Fig. 2) $\left(\mathrm{BSS}^{\circledR}\right.$, Alcon Laboratories Inc., Fort Worth, Texas, USA).

In a next step, the silicone prosthesis (Eickemeyer eye implant, black silicone, 28-33 mm, Eickemeyer KG, Tuttlingen, Germany) was inserted into the eviscerated sclera (Fig. 3). Minor size and shape adjustments of the prosthesis were made by using a scalpel. This precise adjustment of the prosthesis's size and shape was important to allow a strainless suture of the

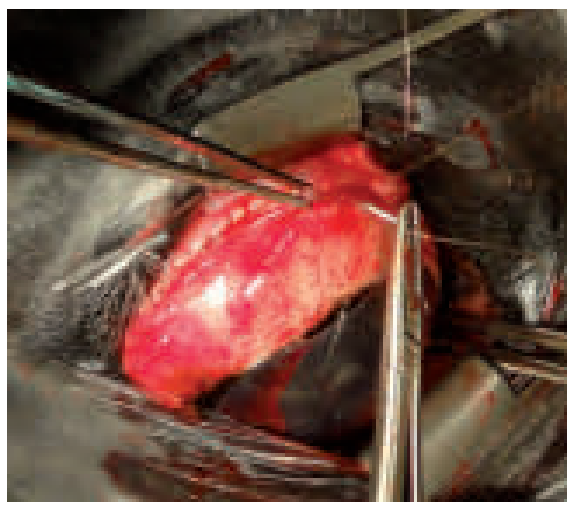

Fig. 4 Right eye of a 12 year-old Dutch warmblood mare during surgery (horse 10). The sclera has been sutured in a simple continuous manner with absorbable suture material. The conjunctiva is closed in a simple continuous pattern with absorbable suture material as well.

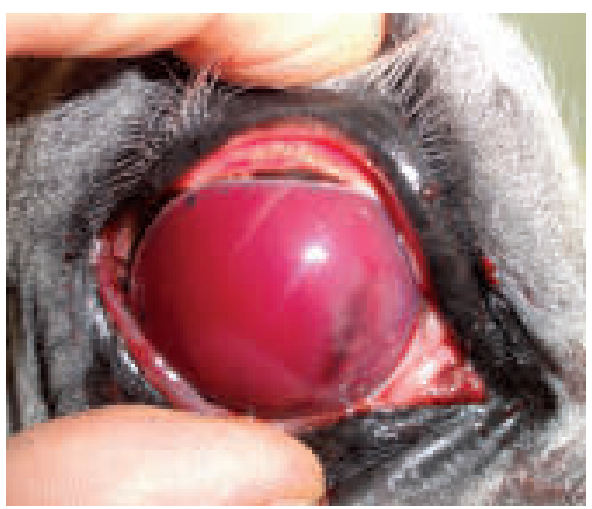

Fig. 5 Right eye of a 12 year-old Dutch warmblood mare a few hours after surgery (horse 10). The red discoloration is due to a typical slight secondary bleeding into the globe that can bee seen through the still clear cornea.

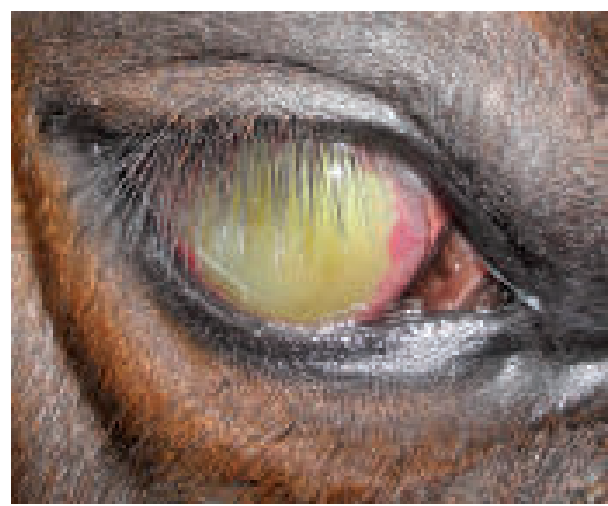

Fig. 6 Right eye of a 14 year-old quarterhorse mare (horse 3), ten days after surgery. A marked neovascularization and yellow discoloration of the cornea is present. This appearance was typical for most cases approximately eight to ten days following surgery. 
sclera. The sclera and the conjunctiva were closed in a simple continuous suture pattern (Fig. 4) (Monosyn ${ }^{\circledR}$ USP 4-0, respectively USP 3-0, B. Braun Melsungen AG, Germany; glyconate). All horses received flunixin meglumine intraoperatively (1.1 mg/kg intravenously). Typically, a slight secondary bleeding into the globe could be seen a few hours following surgery that was resorbed within a few days (Fig. 5). Postoperatively, all horses were treated with flunixin meglumine $(1.1 \mathrm{mg} / \mathrm{kg}$ per os, once daily) over seven days, and antibiotic ophthalmic ointment (gentamicin $5 \mathrm{mg} / \mathrm{g}$, twice daily) over 14 days.

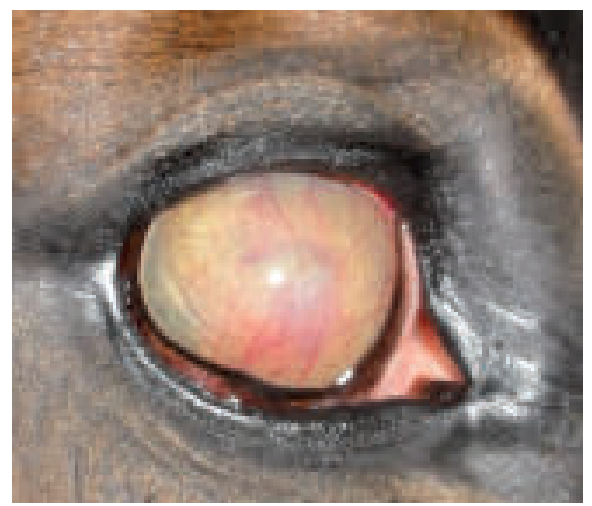

Fig. 7 Right eye of a 14 year-old warmblood gelding (horse 5), six weeks after surgery. Note the blood vessels and the remodelled corneal epithelium.

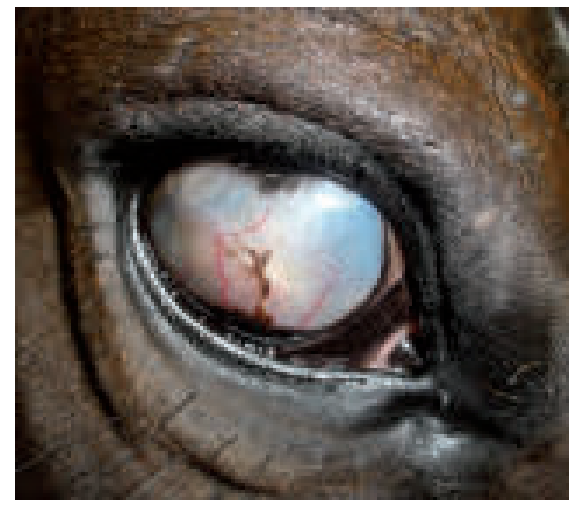

Fig. 8 Right eye of a 14 year-old quarterhorse mare (horse 3), approximately three months after surgery. Note the incipient pigmentation at the dorsal and ventral limbus and the remodelling of the cornea. This appearance could be seen on all cases at this point after surgery, with the exception of the horse with the removed prosthesis (horse 4) and the horses with the eosinophilic keratitis (horse 6 , horse 11).

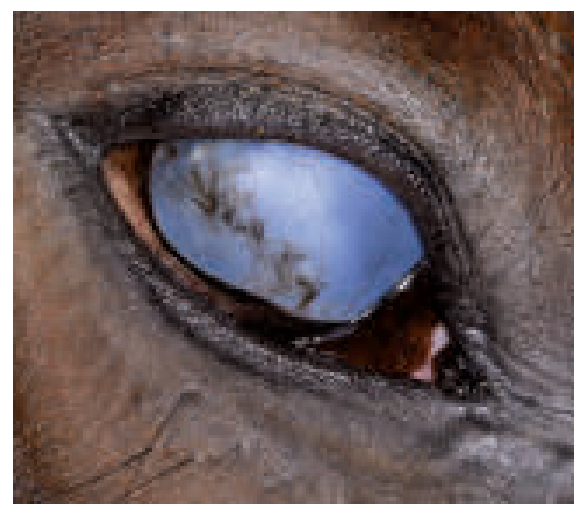

Fig. 9 Right eye of a 14 year-old quarterhorse mare (horse 3), approximately one and a half years after surgery. At this time, the corneal tissue has been completely remodelled into connective tissue.

\section{Results}

The surgical site healed well and without complications in all horses. In one horse (horse 4), a pre-existing corneal ulceration perforated and the prosthesis had to be removed due to intense inflammation two weeks following surgery. This horse had had a deep corneal ulcer extending to the stroma prior to surgery. In the other twelve horses, the cornea of the affected eyes underwent various stages of vascularization and cloudiness (Fig. 6, Fig. 7). An incipient pigmentation of the

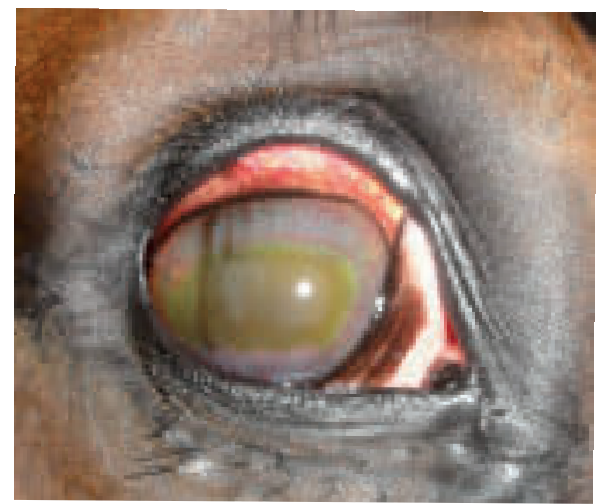

Fig. 10 Right eye of a twelve year-old warmblood gelding (horse 6), eight weeks after surgery. As a complication after surgery, an eosinophilic keratitis had developed and was subsequently subjected to repeat laser treatment.

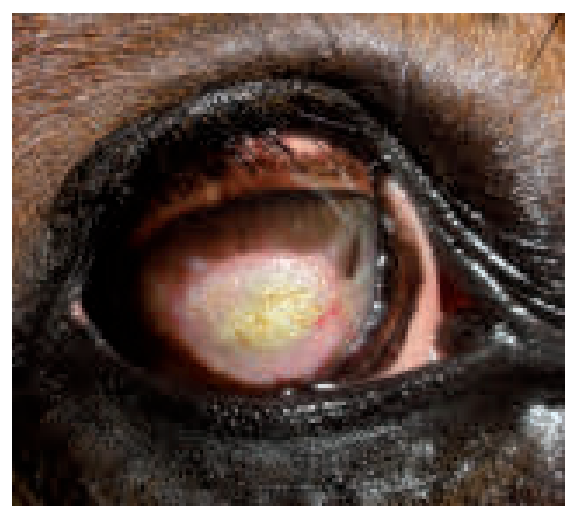

Fig. 11 Right eye of a twelve year-old warmblood gelding (horse 6), approximately nine weeks after surgery. Picture was taken two days after the second laser treatment. Note the punctuated appearance of the central, laser-treated epithelium and the healthy margin of pink granulation tissue surrounding the central area.

cornea as early as nine weeks after surgery could be seen (Fig. 8). On average, it took about three months for the corneal tissue to remodel into connective tissue (Fig. 9). In some cases, the pigmentation of the cornea included almost the whole cornea.

In two horses (horse 6, horse 11), an eosinophilic keratitis developed two months (horse 6) and six weeks (horse 11) after surgery (Fig. 10). The affected cornea was subjected to three sessions of diode laser treatment (Photolase ${ }^{\circledR}$ Diode Laser, Gigaa Optronics Technology Co., Ltd., Wuhan, PRC): Two repeated, single-point firing treatments $(400 \mu \mathrm{m}$ fiber, 4 watts) at an interval of one week and one non-contact softlaser treatment $(400 \mu \mathrm{m}$ fiber, 4 watts) another week later (Fig. 11). The respective eye of those two horses was also treated with an antibiotic and cortisone ophthalmic ointment 


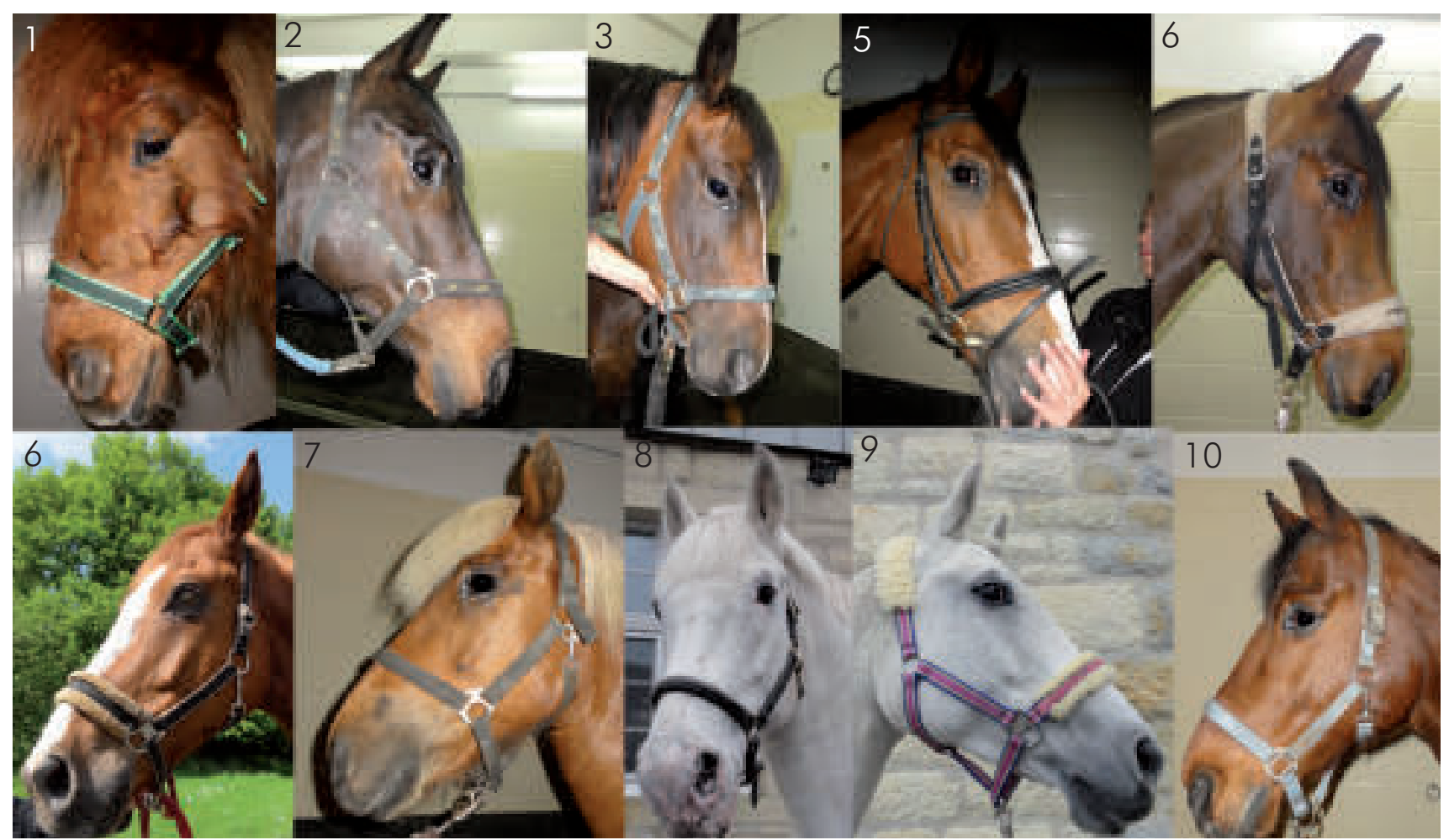

Fig. 12 The ten successfully treated cases, most with tinted bandage lenses in place (all except horse 7). Note the excellent optical appearance of all cases. Horse 4 is not pictured as the prosthesis had to be removed.

$(0.29 \mathrm{~g} / \mathrm{g}$ dexamethasone and $5.76 \mathrm{mg} / \mathrm{g}$ oxytetracycline). The keratitis showed improvement and resolved within two months in both cases.

In one horse (horse 9), a slight swelling of the soft tissues surrounding the eye occurred four days after surgery. The eye and its surroundings were covered with a head bandage that was regularly soaked with mild antiseptic fluids $0,5 \%$ chinolinolsulphate-potassiumsulphate) and the swelling resolved within two days.

Four horses (Horses 1, 2, 4, 5 and 6) received a black bandage lens (Bandage Pat Black, tinted Bandage Lens $\mathrm{Hl}$ and H2 32.0-34.0 cm, Acrivet, Salt Lake City, Utah, USA) that can be placed over the cornea during horse shows or competitions by the owners themselves to achieve an even better cosmetic result once the cornea has completely remodelled (Fig. 12). After each use, the lenses are removed by the owners, cleaned and stored in sterile buffered salt solution. In regular intervals, the lenses are autoclaved in their glass storage containers. There have been no reported losses of lenses or any complications with their use so far. The owners of these horses are very satisfied with the cosmetic appearance of their horses and the overall surgical result.

Horses 1 and 3 went back to being show horses. There have been no complications reported by their owners. Horses 2, 5, $6,7,9,10$ and 11 were continued to be used as sport horses in competitions. All horses are coping well according to their owners and competing successfully up to international levels. One of these horses, horse 2, has been sold in the meantime and is mainly being used as a dressage horse and in lower level show jumping competitions. The new owners are very satisfied with the performance and appearance of the horse.
Horse 8 has been returned to its use as a therapy horse. Horses 12 and 13 are still recovering from surgery, but the healing of the surgical sites has been unremarkable and satisfactorily in these patients so far. The observation period of the described thirteen cases ranges between one month (horses 12 and 13) and three years (horse 1).

\section{Discussion}

Horse owners have very high aesthetic demands when it comes to the appearance of their horses, especially in regard to show or competition horses and representative horses such as circus horses. Modern plastic surgery allows functional and cosmetic reconstruction in equine medicine (Pierce and Townsend 2012, Toth et al. 2011). The intrascleral prosthesis enhances the optical appearance of horses with disfiguring ocular problems as the appearance of an empty orbit or a horse with only one eye is in select cases (show or competition horses, representative horses) not acceptable for the owners (Gilger et al. 2003, Hamor et al. 1992, Riggs and Whitley 1990, Ruehli et al. 1999). When it comes to cosmetic surgery in animals, one surely has to question whether the intended procedure holds any advantage for the patient or whether it is solely for the owner's benefit. If the latter is the case, it shall at any rate not cause the patient harm, discomfort or pain (Riggs and Whitley 1990, Ruehli et al. 1999, Toth and Hollerrieder 1999, Toth et al. 2011 ).

The above described surgery can only be performed under general anaesthesia, as opposed to an enucleation of the whole globe which can be performed in the standing horse. In that regard, the latter surgery can be regarded as less stressful for the horse and also less cost-intensive. The former 
surgery, though, if performed carefully and successfully, produces permanent analgesia in the horse, as well as a cosmetically representative appearance (Gelatt and Whitley 2011 , Gilger et al. 2003, Hamor et al. 1992, Hamor et al. 1993, Nasisse et al. 1988, Provost et al. 1989, Riggs and Whitley 1990). Also, any permanently necessary medication such as anti-inflammatory medications or ophthalmic ointments containing cortisone and antimicrobials can be discontinued after surgery, lowering the risks of adverse side effects such as gastric ulcers (Riggs and Whitley 1990, Toth et al. 2011).

Intrascleral prostheses, as opposed to scleral shell prostheses or scleral conformers, have the advantage that the affected eye has a normal motility after surgery (Gilger et al. 2003, Shields et al. 1993). Regularly, the cornea will vascularize and scar within a few weeks which can cause a cosmetically undesirable result until pigmentation occurs. The use of a bandage lens can further improve the cosmetic result; it is cheaper than a scleral conformer and easy to apply by the owner (Gelatt and Whitley 2011 , Pierce and Townsend 2012, Riggs and Whitley 1990, Toth and Hollerrieder 1999, Toth et al. 2011). After placement of the bandage lens, the motility of the eye may appear somewhat reduced as the lens does not completely match the eye's movements. However, due to the dark color of the lens, this effect is very subtle.

An alternative surgical procedure is the placement of a corneoscleral prosthesis made from hydroxyapatite after enucleation of the globe (Gilger et al. 2003). This is a very intricate and extensive surgery as a donor sclera with a hydroxyapatite prosthesis is employed and the ocular muscles must be adapted to the new sclera to allow for prosthesis movement. Hydroxyapatite has a good host adaptation and shows little to no rejection; it is light weight and has an enhanced biocompatibility (Gilger et al. 2003, Shields et al. 1993). To further improve the cosmetic result of this surgery, a scleral conformer or external prosthesis is needed as well (Gilger et al. 2003, Pierce and Townsend 2012, Shields et al. 1993).

Corneal diseases, diseases of the eyelids and nicitating membrane are still a possible threat in patients that have received an intrascleral prosthesis and they will require medical treatment (Gelatt and Whitley 2011). It is proposed that eyes which have received prostheses are more prone to injury as the horse cannot see any objects moving toward the eye (Riggs and Whitley 1990, Severin 1998). On the other hand, the surface sensibility and reflexes are preserved, protecting the eye from possible insults.

The potential complications arising from this surgical method are prosthesis extrusion, dehiscence of the surgical site, endophthalmitis (septic and aseptic), severe swelling, and poor cosmesis as well as poor motility, prosthesis migration and deformity (Gilger and McLaughlin 1993, Riggs and Whitley 1990, Severin 1998, Shields et al. 1993, Toth and Hollerrieder 1999). In such cases, the prosthesis can always be removed at a later time (Pierce and Townsend 2012, Riggs and Whitley 1990). The remaining wound can be sutured or allowed to heal by secondary intention (Toth and Hollerrieder 1999).

The most common post-surgical complication is corneal ulceration. Eyes with pre-existing corneal disease are at a higher risk of developing complications such as keratitis or ulceration
(Gelatt and Whitley 2011 , Pierce and Townsend 2012, Riggs and Whitley 1990). This could be explained by the missing supply of corneal nutrition through the aqueous fluid and the post-surgical remodeling processes of the cornea. Horse 4 had a deep corneal ulceration prior to surgery. The owner of said horse was informed of the higher risk of post-surgical complications but still wanted the procedure performed. Originally, it was planned to treat the corneal ulceration with a conjunctival flap during surgery. This procedure had to be abandoned as the horse displayed severe cardiovascular anaesthetic complications, potentially because of the older age of the horse. The medical treatment of the ulceration was continued after surgery but proved unsuccessful. A second general anaesthesia for placement of a conjunctival flap was not advised due to the anaesthetic risk and was also refused by the owner.

Two patients developed an eosinophilic keratitis post-operatively (horse 6, horse 11). Horse 6 had had a history of equine recurrent uveitis and subsequently had to have surgery due to the disease. Both equine recurrent uveitis as well as eosinophilic keratitis are immune-mediated diseases. Whether there is a connection between those two diseases as in this case is still not clear. Horse 11 had a keratitis vasculosa prior to surgery which may have predisposed the eye to the post-surgical development of the eosinophilic keratitis.

There is a certain disagreement in literature whether corneal lacerations are a contraindication to the placement of intrascleral prostheses (Gelatt and Whitley 2011, Pierce and Townsend 2012, Riggs and Whitley 1990). In the case of horse 2 , the corneal laceration was surgically corrected and allowed to heal before placement of the prosthesis. This may have positively affected the outcome of the case.

The placement of an intrascleral prosthesis combines the necessary removal of a painful and blind eye's contents and the cosmetic enhancement of a disfiguring condition as the post-surgical appearance is more cosmetic than after an enucleation.

\section{Conflict of Interest statement}

The authors declare that there is no financial or other conflict of interest concerning the content or publication of this article.

\section{References}

Dortzbach R. K., Woog J. J. (1985) Choice of procedure. Enucleation, evisceration, or prosthetic fitting over globes. Ophthalmology 92, 1249-1255

Gelatt K. N., Whitley K. D. (2011) Surgery of the orbit. In: Veterinary Ophthalmic Surgery. (eds. Gelatt K.N. and Gelatt J.P.). Saunders: Philadelphia, 51-88

Gilger B. C., McLaughlin S. A. (1993) Glaucoma and corneal stromal abscess in a horse treated by an intraocular silicone prosthesis and a conjunctival pedicle flap. Equine Pract. 15, 10-15

Gilger B. C., Pizzirani S., Johnston L. C., Urdiales N. R. (2003) Use of a hydroxyapatite orbital implant in a cosmetic corneoscleral prosthesis after enucleation in a horse. J. Am. Vet. Med. Assoc. 222, 343-345

Hamor R. E., Roberts S. M., Severin G. A., Travnik W. R., Johnson W. J. (1992) Ocular cosmetic and prosthetic devices. Veterinary Clinics of North America, Large Anim. Pract. 8, 637-654 
Hamor R. E., Roberts S. M., Severin G. A. (1993) Use of orbital implants after enucleation in dogs, horses, and cats: 161 cases (1980-1990). J. Am. Vet. Med. Assoc. 203, 701-706

Hentscher H. G. (1977) Augenprothese beim Pferd. Prakt. Tierarzt $58,176-179$

Lavach J. D., Severin G. A. (1990) Equine ocular cosmesis. Vet. Clin. North Am. Large Anim. Pract. 6, 489-499

McMullen R. J., Davidson M. G., Campbell N. B., Salmon J. H., Gilger B. C. (2010) Evaluation of 30- and 25-diopter intraocular lens implants in equine eyes after surgical extraction of the lens. Am. J. Vet. Res. 71, 809-816

Meek L. A. (1988) Intraocular silicone prosthesis in a horse. J. Am. Med. Assoc. 193, 343-345

Michau T. M., Gilger B. C. (2004) Cosmetic globe surgery in the horse. Vet. Clin. North Am. Large Anim. Pract. 20, 467-484

Nasisse M. P., van Ee R. T., Munger R. J., Davidson M. G. (1988) Use of methyl methacrylate orbital prostheses in dogs and cats: 78 cases (1980-1986). J. Am. Vet. Med. Assoc. 192, 539-542

Pierce K. E., Townsend W. M. (2012) Surgery of the Globe and Orbit. In: Equine Surgery 4th edition (eds. Auer J.A. and Stick J.A.). Saunders: Philadelphia, 728-743

Provost P. J., Ortenburger A. I., Caron J. P. (1989) Silicone ocular prosthesis in horses: 11 cases (1983-1987). J. Am. Vet. Med. Assoc. 194, 1764-1766

\section{Einsatz eines intraskleralen Silikonimplantates nach Eviszeration des Bulbus bei dreizehn Pferden}

\section{Zusammenfassung}

Ziel der Arbeit: Die vorliegende Arbeit befasst sich mit kosmetischer und rekonstruktiver Augenchirurgie beim Pferd in Fällen, in denen traumatische Ereignisse, permanente Entzündung oder Schmerz eine Entfernung des erkrankten Organes erfordern. Material und Methoden: Dreizehn Pferde im Alter zwischen vier und zwanzig Jahren, die an Augenerkrankungen unterschiedlicher Genese litten und deren Besitzer aus verschiedenen Gründen eine Entfernung des Bulbus ablehnten, wurden in Vollnarkose operiert.Nach der sorgfältigen Eviszeration des Bulbus wurde ein Silikonimplantat in die Sklera eingesetzt. Sklera und Konjunktiva wurden nachfolgend verschlossen und die Pferde wurden postoperativ mit NSAIDs und antibiotischen Augensalben behandelt. Nach Abheilung der Operationswunde konnte eine dunkel gefärbte Kontaktlinse von den Besitzern auf das Auge aufgesetz† werden um das kosmetische Ergebnis noch weiter zu verbessern. Ergebnisse: Die Operationswunden heilten bei allen Pferden gut. Ein Pferd hatte bereits pröoperativ ein tiefes Hornhautulkus, welches auch nach der Operation nicht zur Abheilung kam und zwei Wochen nach der Operation eine Entfernung des Implantates notwendig machte. Zwei Pferde entwickelten als Komplikation nach der Operation eine eosinophile Keratitis. Diese wurde bei beiden Pferden wiederholt mit einem Diodenlaser und Augensalbe behandelt und damit zur Abheilung gebracht. Ein Pferd zeigte vier Tage nach der Operation eine leichte Schwellung des Weichteilgewebes in der Augenumgebung, welche mittels eines Angussverbandes behandelt wurde. Die Hornhaut der operierten Augen veränderte sich in den Wochen nach der Operation und durchlief verschiedene Stadien von Trübung, Gefäßeinsprossung, Umbau des Epithels und Pigmentierung. Intrasklerale Silikonimplantate, mit oder ohne Anwendung dunkel gefärbter Kontaktlinsen, erbringen ein hervorragendes kosmetisches Ergebnis,
Riggs C., Whitley R. D. (1990) Intraocular silicone prostheses in a dog and a horse with corneal lacerations. J. Am. Vet. Med. Assoc. $196,617-619$

Rogge G. (2003) Die chirurgische Behandlung von Augenkrankheiten beim Pferd. Diss. Med. Vet. Munich

Ruehli M., von Salis B., Spiess B. (1999) Die Verwendung einer bemalten Kunstoffschale zur Verbesserung des aesthetischen Aussehens bei Pferden mit Phtisis bulbi nach irreversibler Bulbusverletzung oder chronisch-rezidivierender Entzuendung. Pferdeheilkunde 15, 147-150

Severin G. A. (1998) Equine Ophthalmology. Proceedings of the Annual Convention of the American Association of Equine Practitioners 44, 105-124

Shields C. L., Shields J. A., de Potter P., Singh A. D. (1993) Lack of complicaitions of the hydroxyapatie orbital implant in 250 consecutive cases. Transactions of the American Ophthalmological Society 91, 177-189

Toth J., Hollerrieder J. (1999) Verwendung intraorbitaler Silikonprothesen nach Bulbusexstirpation. Pferdeheilkunde 15, 181-183

Toth J., Dikker L., Huthmann S., Hollerrieder J. (2011) Intrasklerale Silikonprothese nach Eviszeration des Bulbus beim Pferd. Prak. Tierarzł 92, 886-890

Wilkie D. A., Gilger B. C., van der Woerdt A., Graenitz U. (1994) Die Implantation von intraokulaeren Silikonprothesen. Prakt. Tierarzt $75,1097-1100$

welches von den Besitzern positiv angenommen wird. Es ist eine kosmetisch überlegene Alternative zur Enukleation oder auch zur Enukleation mit Einsatz eines intraorbitalen Silikonimplantates in Fällen, in denen die Entfernung des blinden und schmerzhaften Auges unausweichlich ist.

Schlüsselwörter: Auge / Pferd / Silikon / Implantat / Eviszeration / Ophthalmologie

\section{Einleitung}

Eine Vielzahl von Augenerkrankungen kann beim Pferd zu Visusverlust und permanentem Schmerz im Bereich des Auges führen, wobei die equine rezidivierende Uveitis mit Abstand eine der häufigsten zU nennenden Ursachen ist. Daneben kommen traumatisch bedingte Verletzungen, Glaukom und Tumoren des Auges als häufigere Ursachen in Frage. Ein normaler Visus und Schmerzfreiheit, die obersten Ziele der veterinärmedizinischen Augenheilkunde, können in solchen Fällen nicht immer erreicht werden. Sofern der kranke und oft auch schmerzhafte Bulbus nicht erhalten werden kann, muss er entfernt werden. Auf der anderen Seite empfinden viele Pferdebesitzer das entfernte und dann eingesunkene Pferdeauge als abstoßend und für sie ist es wichtig, die natürliche Schönheit und das unberührte Aussehen des Pferdes zu erhalten. Zu diesen ästhetischen und emotionalen Bedenken kommen auch wirtschaftliche Gründe hinzu, da der Verlust eines Auges häufig auch einen Wertverlust des Pferdes bedeutet (Gilger et al. 2003, Hamor et al. 1992, Michau und Gilger 2004, Riggs und Whitley 1990, Ruehli et al. 1999, Severin 1998, Toth und Hollerrieder 1999, Toth at al. 2011). In solchen Fällen besteht die Aufgabe des Tierarztes darin, sowohl eine daverhafte Schmerzfreiheit für das Pferd als auch eine kosmetisch akzeptable Lösung für den Tierbesitzer zu finden (Riggs und Whitley 1990, Toth at al. 2011).

Kosmetische Chirurgie am Auge und Augenprothesen haben eine lange Vergangenheit in der Tiermedizin. Dabei reflektieren die verwendeten Materialien nicht nur die Epoche, in der 
sie eingesetzt wurden, sondern auch die beabsichtigte chirurgische Maßnahme, wie z. B. intraorbitale Prothese, Skleralschale oder intrasklerale Prothese. In der Literatur werden verschiedene Materialien wie z. B. Horn, Glas, Gummi, Silikon, Methylmethacrylat, Plastik, Silberdrahtgeflecht, Porzellan und Hydroxyapatit beschrieben (Dortzbach und Woog 1985, Gelatt und Whitley 2011, Gilger et al. 2003, Hamor et al. 1993, McMullen et al. 2010, Meek 1988, Pierce and Townsend 2012, Provost et al. 1989, Riggs and Whitley 1990, Ruehli et al. 1999, Severin 1998, Shields et al. 1993, Toth und Hollerrieder 1999, Toth et al. 2011 , Wilkie et al. 1994). In der Humanmedizin ist Hydroxyapatit das mit Abstand am häufigsten genutzte Material; es besteht aus Meereskoralle (Gilger et al. 2003, Shields et al. 1993). Dieses Material wurde auch beim Pferd bereits als intrasklerale Prothese verwendet (Gilger et al. 2003). Silikon findet in der Veterinärmedizin als Prothesematerial sowohl bei intraokulären als auch bei intraskleralen Prothesen breite Verwendung, da es kostengünstig, formbar und sterilisierbar ist (Gelatt und Whitley 2011 , Gilger et al. 2003, Hamor et al. 1993, Meek 1988, Provost et al. 1989, Riggs und Whitley 1990, Severin 1998, Toth und Hollerrieder 1999, Toth et al. 2011, Wilkie et al. 1994).

Während das Einbringen introkulärer Prothesen ein häufig in der Pferdemedizin durchgeführter Eingriff ist, der sogar am stehenden Patienten durchgeführt werden kann, werden intrasklerale Prothesen bei Pferden deutlich seltener implantiert. Im Gegensatz dazu werden intrasklerale Prothesen bei anderen Spezies, z. B. bei Hunden mit chronischem Glaukom, öfter und mit einer niedrigen Komplikationsrate eingesetz† (Hamor et al. 1993, Nasisse et al. 1988, Riggs und Whitley 1990, Toth und Hollerrieder 1999).

Der Einsatz intraskleraler Prothesen beim Pferd wird durch einige Auswahlkriterien begrenzt. Dabei müssen besonders infizierte Augen und Augen mit Neoplasien gründlich auf ihre Operationsfähigkeit untersucht werden (Dortzbach und Woog 1985, Pierce und Townsend 2012, Provost et al. 1989, Riggs und Whitley 1990, Ruehli et al. 1999, Shields et al. 1993, Toth et al. 2011). Augen mit Hornhautverletzungen oder Skleradefekten sind in Hinsicht auf eine erfolgreiche Operation prognostisch vorsichtig zu bewerten (Pierce und Townsend 2012, Riggs und Whitley 1990). Pferde mit Glaukom oder Phtisis bulbi und Pferde mit blinden, schmerzhaften Augen oder aber traumatisch bedingten Verletzungen können grundsätzlich als geeignete Kandidaten für den Einsatz einer intraskleralen Prothese betrachtet werden (Gelatt und Whitley 2011, Gilger und McLaughlin 1993, Provost et al. 1989, Riggs und Whitley 1990, Toth et al. 2011). Zusammenfassend sind die idealen Voraussetzungen für diese Operation eine intakte Sklera, eine gesunde Hornhaut, ein physiologischer Tränenfilm sowie eine normale Funktion der Augenlider (Gilger und McLaughlin 1993, Toth et al. 2011).

\section{Material und Methoden}

\section{Fälle}

Zwischen Dezember 2011 und Oktober 2013 wurden in der Tierärztlichen Klinik Domäne Karthaus dreizehn Patienten, die aufgrund unterschiedlicher ophthalmologischer Probleme (siehe unten) behandelt wurden, als geeignete Kandidaten für den Einsatz einer intraskleralen Silikonprothese ausgewähl† (Tabelle 1).
Pferd 1 war ein zwölfjähriger Reitponywallach mit einer mehr als vier Jahre zurückdatierenden Anamnese rezidivierender Uveitis des linken Auges. Bei der Eingangsuntersuchung wurde die Prognose für das Auge als schlecht eingestuft, da bei der Ultraschalluntersuchung eine große Menge an flotierenden Membranen im Glaskörper sowie eine Netzhautablösung dargestellt werden konnten. Das Auge war blind und daverhaft schmerzhaft und den Besitzern wurde eine Enukleation des Auges empfohlen. Da der Besitzer das Pony als Showpferd weiter nutzen wollte, bat er um eine chirurgische Lösung, die sowohl eine Schmerzfreiheit für das Pony als auch ein kosmetisch vertretbares Ergebnis erzeugt.

Pferd 2 war ein vieriähriger Holsteinerwallach, der im Notdienst mit einer perforierenden Verletzung der Hornhaut des rechten Auges vorgestellt wurde. Laut Besitzerangaben hatte der Wallach sich mit der Kette, an der er angebunden war, verletzt. Die Verletzung war etwa $1 \mathrm{~cm}$ lang; die Iris sowie der Glaskörper waren prolabiert. Zudem lagen ein Hyphaema sowie eine ausgeprägte Miosis vor. Das Pferd wurde in Allgemeinanästhesie verbracht und die Verletzung der Hornhaut wurde chirurgisch verschlossen. Außerdem wurde eine Vitrektomie der vorderen und hinteren Augenkammer durchgeführt. Ełwa einen Monat nach der Operation war die Hornhautverletzung zwar gut verheilt, jedoch war es aufgrund einer massiven traumatisch bedingten Uveitis zu einer Phtisis bulbi gekommen. Da das Pferd jung und sehr begabt war und der Besitzer es als Sportpferd einsetzen wollte, bat er um eine Operation mit optisch gutem Ergebnis.

Pferd 3 war eine vierzehniährige Quarterhorsestute, die eine lange Anamnese ophthalmologischer Probleme aufgrund rezidiviereder Uveitis hatte. Fünf Jahre vor Überweisung war das rechte Auge der Stute vitrektomiert worden. Zum Zeitpunkt der Überweisung war die Hornhaut des rechten Auges wolkig und trüb; es lagen zudem ein Hornhautdefekt, eine Gefäßeinsprossung in die Hornhaut und eine Luxation der Linse in die vordere Augenkammer vor. Das Auge war extrem schmerzhaft, woraufhin eine Entfernung des Auges angeraten wurde. Da es sich bei dem Pferd um ein erfahrenes und wertvolles Showpferd handelte, wollte der Besitzer ein gutes kosmetisches Resultat.

Pferd 4 war eine zwanzigiährige Shetlandponystute mit einer rezidivierenden Uveitis des linken Auges. Das Auge zeigte trotz Vitrektomie vor zwei Jahren wiederkehrende Uveitisschübe. Zum Zeitpunkt der Vorstellung war das linke Auge akut entzündet und wies einen etwa $1 \mathrm{~cm}$ großen Hornhautdefekt auf, der bis ins Stroma reichte. Der Besitzer wünschte eine daverhafte Lösung für die Entzündungsschübe mit einem kosmetisch akzeptablen Ergebnis, da es sich bei dem Pony um ein Showpferd handelte.

Pferd 5 war ein vierzehnjähriger Westfalenwallach, der vor Überweisung über einen Zeitraum von etwa zwei Monaten aufgrund ophthalmologischer Probleme behandelt worden war. Bei der Eingangsuntersuchung wies der Wallach Epiphora, Blepharospasmus, Photophobie, Miosis und eine Hornhauttrübung des rechten Auges auf. Der Fluoreszein-Test fiel negativ aus; bei der Ultraschalluntersuchung des Auges wurden flotierende Membranen im Glaskörper nachgewiesen. Die Diagnose lautete equine rezidivierende Uveitis des rechten Auges. Trotz konservativ-medikamenteller Behandlung zeigte das Pferd wiederholt Entzündungsschübe, oft auch mit 
Hornhautulzera. Es wurde eine intravitreale GentamicinInjektion durchgeführt, doch der Wallach zeigte unverändert Entzündungszeichen am rechten Auge, zudem entwickelte sich eine behandlungsresistente Hornhautulzeration. Dem Besitzer wurde eine Entfernung des Bulbus nahegelegt, doch da es sich um ein Sportpferd handelte, wünschte der Besitzer eine optisch gute Lösung. Der Besitzer wurde darüber informiert, dass die bestehende Hornhautläsion den Erfolg der Operation möglicherweise kompromittieren könnte.

Pferd 6 war ein zwölfiähriger Westfalenwallach, bei dem zuvor equine rezidivierende Uveitis des rechten Auges diagnostiziert worden war. Der Wallach war zwei Jahre vor der Überweisung chirurgisch mit einem suprachoroidalen Cyclosporin-Implantat versorgt worden, litt aber trotzdem noch unter Uveitisschüben. Kurz vor der Vorstellung war dem Besitzer eine rötliche Verfärbung des Auges aufgefallen. Bei der Eingangsuntersuchung zeigte der Wallach Blepharospasmus, eine Hornhauttrübung, Hyphaema, eine Linsenkatarakt und Phtisis bulbi. Bei der Ultraschalluntersuchung wurden große Mengen an flotierenden Membranen im Glaskörper und eine Netzhautablösung festgestellt. Das Auge war extrem schmerzhaft und eine Enukleation wurde empfohlen. Da es sich bei dem Pferd um ein hocherfolgreiches Dressurpferd im internationalen Sport handelte, wünschte der Besitzer ein kosmetisch optimales Ergebnis.

Pferd 7 war ein siebenjähriger Trakehnerwallach, der als Sportpferd gekauft worden war. Bei der Ankaufsuntersuchung eineinhalb Jahre vor der Erstvorstellung war ein medizinisches Problem am linken Auge festgestellt worden und das Pferd hatte in der Folge immer wieder Probleme mit diesem Auge gehabt. Bei der Eingangsuntersuchung wurde ein Blepharospasmus des linken Auges bemerkt; die Hornhaut war leicht trübe und das Pferd zeigte keine Reaktion auf Licht oder Drohreflex. Am nasalen Augenwinkel konnte ein Hyphaema festgestellt werden und zentral in der Hornhaut befanden sich zwei kleine, fluoreszein-positive Defekte. Die Linse war in die vordere Augenkammer vorgefallen und im Glaskörper befand sich Blut. Da es sich bei dem Pferd um das Turnierpferd der Tochter handelte, entschieden sich die Besitzer gegen eine Entfernung des Augapfels und wünschten eine alternative, kosmetisch gute Lösung.

Pferd 8 war eine fünfzehnjährige Isländerstute, bei der vor zwölf Jahren eine Vitrektomie aufgrund equiner rezidivierender Uveitis durchgeführt worden war. Das Pferd hatte wiederholt Entzündungsschübe und entwickelte schließlich ein Glaukom. Zum Zeitpunkt der Überweisung lagen eine geringgradige Trübung der Hornhaut, Synechien, eine Katarakt und flottierende Membranen im Glaskörper vor. Da das Pferd als Therapiepferd in einem Programm für behinderte Kinder eingesetzt wurde, wünschten die Besitzer ein optisch gutes Resultat.

Pferd 9 war ein neunjähriger Knabstrupperwallach, bei dem ein Jahr vor Vorstellung eine Vitrektomie des linken Auges aufgrund rezidivierender Uveitis durchgeführt worden war. Das Pferd hatte kurz vor Vorstellung einen heftigen Uveitisschub erlitten und in der Folge eine Phtisis bulbi entwickelt. Bei der Untersuchung zeigte der Wallach Blepharospasmus, Epiphora, gerötete Konjunktiven, Hyphaema und Miosis. Da das Pferd ein Showpferd war, wünschte der Besitzer eine chirurgische Lösung mit gutem kosmetischem Ergebnis.
Pferd 10 war eine zwölfjährige Holländische Warmblutstute mit Keratitis vasculosa des rechten Auges. Die Keratitis wurde bereits seit zwei Jahren behandelt. Unter anderem war bei der Stute ein subsklerales Cyclosporinimplantat eingesetzt worden, die Entzündungsschübe traten jedoch immer wieder auf. Als das Pferd an der Klinik vorgestellt wurde, war die Keratitis behandlungsresistent und die Stute hatte sich nach Aussage des Besitzers in ihrem Verhalten so verändert, dass sie aufgrund der ständigen Schmerzen aggressiv geworden war. Bei der Vorstellung war die Augenumgebung des rechten Auges geschwollen. Das Pferd zeigte Epiphora, Blepharospasmus und eine feine Gefäßeinsprossung sowie eine leichte Trübung der Hornhaut. Das Pferd war ein Dressurpferd, das regelmäBig an Turnieren teilnahm, daher entschied der Besitzer sich für eine kosmetisch gute chirurgische Lösung.

Pferd 11 war ein siebenjähriger Holländischer Warmblutwallach mit Keratitis vasculosa des linken Auges. Die Erkrankung war über sechs Wochen, unter anderem mit Kortison, erfolglos behandelt worden und das Auge war extrem schmerzhaft. Bei der Vorstellung zeigte der Wallach Blepharospasmus, Epiphora, eine Hornhauttrübung sowie eine oberflächliche und tiefe Gefäßeinsprossung der Hornhaut. Das Pferd war ein talentiertes Dressurnachwuchspferd und der Besitzer wünschte ein kosmetisch akzeptables Resultat.

Pferd 12 war eine neunjährige Rheinländerstute, die ursprünglich aufgrund einer Hornhautverletzung durch einen Fremdkörper und einer nachfolgenden Pilzinfektion und sekundären Uveitis an die Klinik überwiesen worden war. Die Hornhautverletzung wurde medikamentös und mit einem Konjunktivaflap versorgt; die Uveitis wurde medikamentell behandelt. Der Konjunktivaflap verheilte gut, das Pferd litt jedoch immer wieder unter Uveitisschüben, so dass eine Vitrektomie durchgeführt wurde. Zehn Tage nach erfolgter Vitrektomie zeigte die Stute einen weiteren, milden Uveitisschub. Zu diesem Zeitpunkt war der rechte Bulbus bereits deutlich kleiner als der linke. Da es sich bei dem Pferd um ein erfolgreiches Springpferd handelte, wünschte der Besitzer eine Entfernung des Auges mit gutem kosmetischem Resultat.

Pferd 13 war ein dreizehnjähriger Holländischer Warmblutwallach, der seit Jahren wiederkehrende Keratitisschübe des linken Auges zeigte. Laut Angaben des Besitzers und des überweisenden Tierarztes erfolgten die Schübe in schnellerer Abfolge, waren schwierig zu behandeln und extrem schmerzhaft. Bei der Vorstellung war die Hornhaut des linken Auges weitgehend trübe und es lag ein deutlicher Visusverlust vor. Das Pferd zeigte Epiphora und war bei der Untersuchung ausgesprochen schmerzhaft. Aufgrund der rezidivierenden Symptomatik, dem Visusverlust und der zunehmenden Schmerzhaftigkeit wurde eine Entfernung des schmerzenden Auges empfohlen. Das Pferd war zuvor als Vielseitigkeitspferd eingesetzt worden und sollte nach erfolgter Operation als Dressurpferd eingesetzt werden, weshalb der Besitzer ein optisch akzeptables Resultat wünschte.

\section{Chirurgisches Vorgehen und postoperative Behandlung}

Vor der Operation erhielten alle Pferde eine einzelne (",oneshot") antibiotische Behandlung (Cefquinom 2,5 mg/kg intravenös). Die korrekte Größe der Prothese wurde anhand der bei der präoperativen Ultraschalluntersuchung erfassten 
Daten ermittelt. Die Operation wurde in Allgemeinanästhesie in Seitenlage mit der betreffenden Seite nach oben durchgeführt. Nach aseptischer Vorbereitung des betroffenen Auges wurden zwei Haltefäden (Safil ${ }^{\circledR}$ USP 0, B. Braun Melsungen AG, Deutschland; Polyglycolsäure) in der limbalen Sklera platziert. Der Zugang durch die Sklera wurde unter Schutz eines Konjunktivaflaps durchgeführt. Zu diesem Zweck wurde die Konjunktiva etwa 10-12mm jenseits des Limbus abpräpariert. Daraufhin wurde die Sklera bogenförmig von $120^{\circ}$ bis $180^{\circ}$ durchtrennt (Abb. 1). Der Schnitt wurde vorsichtig zentral bis zur Chorioidea fortgesetzt, dabei wurde besonders darauf geachtet, das Hornhautendothel nicht zu verletzen. Die Uvea wurde an ihrem Ansatz am Sehnerv mit einer Schere abgesetz† ohne dabei die Sklera zu beschädigen. Die verbleibende Uvea wurde stumpf von ihrer Auflage präpariert um ein Blutung zu minimieren, da im Bulbus verbleibendes Blut die Gefahr einer Infektion erhöhen könnte. Der Bulbus wurde vorsichtig mit einem scharfen Löffel enukleiert und die verbleibende Höhle wurde mit balancierter Salzlösung gespült (Abb. 2) (BSS ${ }^{\circledR}$, Alcon Laboratories Inc., Fort Worth, Texas, USA).

Im nächsten Schritt wurde die Silikonprothese (Eickemeyer Augenimplantat, schwarzes Silikon, 28-33 mm, Eickemeyer KG, Tuttlingen, Deutschland) in die ausgehöhlte Sklera eingesetzt (Abb. 3). Kleinere Größen- und Formveränderungen des Implantates konnten mit einem Skalpell vorgenommen werden. Die genaue Anpassung der Größe der Prothese ist wichtig, um eine spannungsfreie Naht der Sklera zu ermöglichen. Die Sklera und die Konjunktiva wurden mit einfacher, fortlaufender Naht verschlossen (Abb. 4) (Monosyn ${ }^{\circledR}$ USP 4-0, bzw. USP 30 , B. Braun Melsungen AG, Deutschland; Glyconate). Alle Pferde erhielten intraoperativ Flunixin Meglumine $(1,1 \mathrm{mg} / \mathrm{kg}$ intravenös). Eine leichte Nachblutung in den Bulbus, welche innerhalb weniger Tage resorbiert wurde, konnte häufig einige Stunden nach erfolgter Operation beobachtet werden (Abb. 5).

Postoperativ wurden alle Pferde über sieben Tage mit Flunixin Meglumine $(1,1 \mathrm{mg} / \mathrm{kg}$ per os, einmal täglich) und über 14 Tage mit antibiotischer Augensalbe (Gentamicin $5 \mathrm{mg} / \mathrm{g}$, zweimal täglich) versorgt.

\section{Ergebnisse}

Die Operationswunde verheilte in allen Fällen komplikationslos. Bei einem Pferd (Pferd 4) brach etwa zwei Wochen nach der Operation ein bestehendes Hornhautulkus durch, woraufhin die Prothese aufgrund einer massiven Entzündung entnommen werden musste. Dieses Pferd hatte bereits vor der Operation ein tiefes, bis in das Stroma reichendes Ulkus aufgewiesen. Bei den anderen zwölf Pferden konnten in den Wochen nach der Operation an der Hornhaut der betroffenen Augen verschiedene Stadien der Vaskularisierung und Trübung beobachtet werden (Abb. 6, Abb. 7). Eine beginnende Pigmentierung der Hornhaut konnte schon neun Wochen nach der Operation festgestellt werden (Abb. 8). Im Durschnitt daverte es etwa drei Monate, bis das Gewebe der Hornhaut sich in Bindegewebe umgebaut hatte (Abb. 9). In einigen Fällen betraf die Pigmentierung fast die gesamte Hornhaut.

Bei zwei Pferden (Pferd 6, Pferd 11) entwickelte sich acht (Pferd 6) bzw. sechs Wochen (Pferd 11) postoperativ eine eosinophile Keratitis (Abb. 10). Die betroffene Hornhaut wur- de einer dreimaligen Behandlung mit einem Diodenlaser (Photolase $^{\circledR}$ Diode Laser, Giga Optronics Technology Co., Ltd., Wuhan, PRC) unterzogen: Zwei wiederholte, Einzelpunktbehandlungen $(400 \mu \mathrm{m}$ Faser, 4 Watt) in einwöchigem Abstand, gefolgt von einer "non-contact" Softlaserbehandlung $(400 \mu \mathrm{m}$ Faser, 4 Watt) eine Woche später (Abb. 11). Das jeweilige Auge dieser beiden Pferde wurde außerdem mit einer antibiotischen und einer kortisonhaltigen Augensalbe behandelt $(0,29 \mathrm{~g} / \mathrm{g}$ Dexamethason and 5,76 mg/g Oxyłetrazyklin). Die Keratitis heilte ab und verschwand innerhalb von zwei Monaten in beiden Fällen.

Bei einem Pferd (Pferd 9) trat vier Tage nach erfolgter Operation eine leichte Schwellung der Augenumgebung des betroffenen Auges auf. Das Pferd erhielt daraufhin einen Kopfverband, der mit milder Desinfektionslösung (0,5\% Chinosolsulfat-Kaliumsulfat) getränkt wurde, woraufhin die Schwellung innerhalb von zwei Tagen zurückging.

Vier Pferde (Pferde 1, 2, 4, 5 und 6) erhielten eine schwarze Kontaktlinse (Bandage Pat Black, tinted Bandage Lens $\mathrm{Hl}$ und H2 32.0-34.0 cm, Acrivet, Salt Lake City, Utah, USA), welche vom Besitzer während Turnieren oder Shows auf die Hornhaut gesetzt werden kann, um ein noch besseres kosmetisches Resultat zu erzielen (Abb. 12). Nach jedem Gebrauch werden die Linsen von den Besitzern entfernt, gereinigt und in steriler, gepufferter Salzlösung aufbewahrt. In regelmäßigen Abständen werden die Linsen in ihren Glasaufbewahrungsgefäßen autoklaviert. Bislang wurden uns noch keine Verluste oder Komplikationen hinsichtlich der Kontaktlinsen berichtet. Die Besitzer dieser Pferde sind mit dem kosmetischen Ergebnis der Operation und der äußeren Erscheinung ihrer Pferde sehr zufrieden.

Pferd 1 und Pferd 3 werden wieder als Showpferde eingesetzt. Von ihren Besitzern wurden uns keine Komplikationen berichtet. Die Pferde 2, 5, 6, 7, 9, 10 und 11 sind wieder im sportlichen Einsatz als Turnierpferde. Die Pferde zeigen keinerlei Anpassungsschwierigkeiten und sind bis zum internationalen Level erfolgreich. Eines dieser Pferde, Pferd 2, ist in der Zwischenzeit verkauft worden und wird in Dressurprüfungen und kleineren Springprüfungen eingesetzt. Die neuen Besitzer sind sehr zufrieden mit der Leistung und dem äußeren Erscheinungsbild des Pferdes. Das Pferd 8 wird wieder als Therapiepferd genutzt. Pferd 12 und Pferd 13 befinden sich noch in der Rekonvaleszenzzeit; die Heilung der Operationswunden verläuft jedoch komplikationslos und zufriedenstellend. Der Beobachtungszeitraum der beschriebenen dreizehn Fälle liegt zwischen einem Monat (Pferd 12, Pferd 13) und drei Jahren (Pferd 1).

\section{Diskussion}

Pferdebesitzer haben sehr hohe ästhetische Ansprüche an das Äußere ihrer Pferde, insbesondere wenn es sich um Turnieroder Showpferde oder repräsentative Pferde wie z. B. Zirkuspferde handelt. Die moderne plastische Chirurgie ermöglicht funktionale und kosmetische Rekonstruktion auch in der Pferdemedizin (Pierce und Townsend 2012, Toth et al. 2011). Die intrasklerale Prothese verbessert das Aussehen von Pferden mit anderenfalls entstellenden ophthalmologischen Problemen wie einer leeren Augenhöhle oder nur einem Auge, welche in bestimmten Fällen (Show- oder Turnierpferde, reprä- 
sentative Pferde) für den Besitzer nicht annehmbar wären (Gilger et al. 2003, Hamor et al. 1992, Riggs und Whitley 1990, Ruehli et al. 1999). Sicherlich sollte man sich im Falle von kosmetischer Chirurgie in der Veterinärmedizin die Frage stellen, ob die vorgesehene Maßnahme auch dem Tier nutz†, oder nur dem Besitzer. Im letzteren Fall darf die Prozedur keinesfalls dem Tier schaden oder ihm Schmerzen verursachen (Riggs und Whitley 1990, Ruehli et al. 1999, Toth und Hollerrieder 1999, Toth et al. 2011 ).

Im Gegensatz zu einer Entfernung des gesamten Bulbus, die auch am stehenden Patienten erfolgen kann, kann die oben beschriebene Operation nur in Allgemeinanästhesie durchgeführt werden. Daher kann die Entfernung des gesamten Bulbus als schonender für den Patienten und auch weniger kostenintensiv angesehen werden. Die oben beschriebene Operation führt jedoch, wenn sie sorgfältig und erfolgreich durchgeführt wird, auch zu einer daverhaften Schmerzlosigkeit des Patienten und ergibt zudem ein kosmetisch akzeptables Ergebnis (Gelatt und Whitley 2011, Gilger et al. 2003, Hamor et al. 1992, Hamor et al. 1993, Nasisse et al. 1988, Provost et al. 1989, Riggs und Whitley 1990). Hinzu kommt, dass eine Davermedikation mit entzündungshemmenden Medikamenten oder kortison- und antibiotikahaltigen Augensalben abgesetzt werden kann, was das Risiko von Nebenwirkungen wie z. B. Magengeschwüren senkt (Riggs und Whitley 1990, Toth et al. 2011).

Im Gegensatz zu Skleralschalen hat die intrasklerale Prothese den Vorzug, dass das betroffene Auge nach der Operation zu normalen Bewegungen fähig ist (Gilger et al. 2003, Shields et al. 1993). Häufig kommt es zu Narbenbildung oder Vaskularisierung der Hornhaut, was ein kosmetisch unschönes Resultat darstellen kann, bis eine Pigmentierung der Hornhaut eintritt. Die Verwendung einer gefärbten Kontaktlinse kann das kosmetische Ergebnis noch verbessern; sie isł günstiger als eine Skleralschale und kann leicht vom Besitzer angewandt werden (Gelatt und Whitley 2011, Pierce und Townsend 2012, Riggs und Whitley 1990, Toth und Hollerrieder 1999, Toth et al. 201 1). Nach dem Einsetzen der Kontaktlinse kann die Beweglichkeit des Auges etwas herabgesetzt erscheinen, da die Linse sich nicht vollständig der Augenbewegung anpasst. Aufgrund der dunklen Farbe der Linse ist dieser Effekt allerdings sehr subtil. Eine chirurgische Alternative ist der Einsatz einer corneoskleralen Prothese aus Hydroxyapatit nach Enukleation des Bulbus (Gilger et al. 2003). Es handelt sich um eine sehr komplizierte und umfangreiche Prozedur, da eine Spendersklera mit einer Hyroxyapatitprothese eingesetzt werden muss, an welche die Augenmuskeln adaptiert werden müssen um eine Augenbewegung zu ermöglichen. Hydroxyapatit wird gut vom Empfänger angenommen und nur selten abgestoßen, es ist leicht und hat eine gute Biokompatibilität (Gilger et al. 2003, Shields et al. 1993). Um das kosmetische Ergebnis dieser Operation weiter zu verbessern, muss auch hier eine Skleralschale oder Augenprothese verwendet werden (Gilger et al. 2003, Pierce and Townsend 2012, Shields et al. 1993).

Erkrankungen der Hornhaut, der Lider und der Nickhaut können bei Patienten mit intraskleraler Prothese auftreten und müssen medikamentell behandelt werden (Gelatt und Whitley 2011). Einige Autoren geben an, dass Augen mit Prothese anfälliger für Verletzungen sind, da das Pferd Gegenstände, die sich auf das Auge zu bewegen, nicht sehen kann (Riggs und Whitley 1990, Severin 1998). Auf der anderen Seite bleiben die Oberflächensensibilität und die Reflexe erhalten, was wiederum das Auge vor möglichen Verletzungen schütz†.

Die möglichen Komplikationen, die in Folge der Operation auftreten können sind Prothesenabstoßung, Dehiszenz, Endophthalmitis (septisch und aseptisch), massive Schwellung, schlechtes kosmetisches Ergebnis, reduzierte Beweglichkeit, Prothesenmigration und Deformation (Gilger und McLaughlin 1993, Riggs und Whitley 1990, Severin 1998, Shields et al. 1993, Toth und Hollerrieder 1999). In solchen Fällen kann die Prothese jederzeit entfernt werden (Pierce und Townsend 2012, Riggs und Whitley 1990). Die verbleibende Wunde kann entweder primär verschlossen werden oder durch sekundäre Wundheilung abheilen (Toth und Hollerrieder 1999).

Die häufigste Komplikation ist die Bildung von Hornhautulzera, wobei Augen, die bereits präoperativ Hornhauterkrankungen aufweisen ein höheres Risiko aufweisen, auch postoperativ Komplikationen wie Keratitis oder Ulzera zu entwikkeln Gelatt und Whitley 2011, Pierce und Townsend 2012, Riggs und Whitley 1990). Dies könnte durch die fehlende Ernährung der Hornhaut durch das Kammerwasser oder die postoperativen Umbauprozesse des Hornhautepithels erklärt werden. Pferd 4 hatte präoperativ ein tiefes Hornhautulkus. Der Besitzer des besagten Pferdes war über das erhöhte Risiko postoperativer Komplikationen informiert worden, wollte die Operation aber trotzdem durchgeführt haben. Ursprünglich sollte das Ulkus intraoperativ mit einem Konjunktivalflap versorgt werden. Dieses Unterfangen musste jedoch abgebrochen werden, da das Pferd schwere kardiovaskuläre anästhetische Kompliaktionen zeigte, möglicherweise aufgrund des schon fortgeschrittenen Alters des Pferdes. Die medikamentelle Behandlung des Ulkus wurde postoperativ fortgesetzt, blieb jedoch ohne Erfolg. Eine zweite Allgemeinanästhesie für das Anlegen eines Konjunktivalflaps konnte aufgrund des erhöhten Narkoserisikos nicht empfohlen werden und wurde darüber hinaus auch vom Besitzer abgelehnt.

Zwei Patienten entwickelten postoperativ eine eosinophile Keratitis (Pferd 6, Pferd 11). Pferd 6 litt unter rezidivierender Uveitis und wurde aufgrund der Erkrankung auch operiert. Sowohl die rezidivierende Uveitis als auch die eosinophile Keratitis sind immunmediierte Erkrankungen. Inwiefern eine Verbindung zwischen diesen beiden Erkrankungen besteht wie in diesem Fall ist noch nicht erforscht. Pferd 11 hatte präoperativ eine Keratitis vasculosa, welche möglicherweise das Auge für die Entwicklung der postoperativen eosinophilen Keratitis prädisponiert hat.

In der Literatur gibt es verschiedene Ansichten dazu, ob Hornhautverletzungen eine Kontraindikation für den Einsatz einer intraskleralen Prothese darstellen (Gelatt und Whitley 2011, Pierce und Townsend 2012, Riggs und Whitley 1990). Im Fall von Pferd 2 wurde die Verletzung zunächst chirurgisch korrigiert und konnte ausheilen, bevor die Prothese eingesetzt wurde. Dies könnte das erfolgreiche Ergebnis dieses Falles positiv beeinflusst haben.

Der Einsatz intraskleraler Prothesen verbindet die notwendige Entfernung des Inhaltes eines schmerzenden und blinden Auges mit der kosmetischen Aufwertung eines anderenfalls entstellten Aussehens. 